\title{
Knowledge, Attitude and Practice Towards Road Traffic Regulations Among University Students, Malaysia
}

\author{
Redhwan AA and Karim AJ \\ Department of Medical Science, International Medical School, Management and Science University (MSU), \\ 40100, Shah Alam, Selangor Darul Ehsan, Malaysia
}

\begin{abstract}
Introduction: Each year, more than 20 million people are injured and 1.17 million are killed due to road traffic accidents. Developing countries account for over $85 \%$ of the deaths, and close to $90 \%$ of the disability caused by road traffic crashes worldwide. The objectives of this study were to determine the knowledge, attitudes and practice and the factors influencing university students in Malaysia concerning road traffic accident. Materials and Methods: This study was conducted among the students of Management and Science University, Malaysia. The questionnaire was distributed randomly to the students of the Faculty of Health and Life Sciences. Data was analyzed using SPSS version 13, T-test and ANOVA. Results: The total number of 109 students with the mean age of $20.94 \pm 1.89$ years participated in this study. Approximately 39 (35.7\%) of the participant had been involved in one or more than one road traffic accident. About $93.6 \%$ of them were very strongly/strongly convinced of seat belts importance. Multivariate analysis using the multiple linear regression method showed that age and attitude were significantly associated with the exposure to the accident. Conclusion: The study participants had moderate knowledge about road traffic regulations and most of them mentioned that high speed, drivers' lack of awareness about traffic regulation and laws, and drivers' non-compliance with traffic rules and regulation were the most important cause of road traffic accidents. Almost all students were very strongly/strongly convinced of seatbelts importance. Age and attitude were significantly associated with the exposure to the accident.
\end{abstract}

\section{KEYWORDS: Attitude, knowledge practice, road traffic regulation, university students}

\section{INTRODUCTION}

Road traffic accidents are defined as fatal or non-fatal injuries incurred as the result of road traffic crashes. The crash is defined as a collision or incidence that may or may not lead to injury, occurring on a public road and involving at least one moving vehicle. ${ }^{1}$ Each year, more than 20 million people were injured or crippled and 1.17 million killed due to road traffic accidents. ${ }^{2-4}$ This represents an average of 3,242 persons dying each day worldwide. In addition to these deaths, between 20 and 50 million people globally are estimated to be injured or disabled every year. ${ }^{1}$

Accidents are not frequently due to ignorance, but are due to carelessness, thoughtlessness and over confidence. Robertson and researchers from Road Safety Agency in USA have pointed out that road accidents

Corresponding address

Redhwan Ahmed Al-Naggar

International Medical School,

Management and Science University (MSU),

Shah Alam, Malaysia

e-mail: radhwan888@yahoo.com were associated with numerous problems each of which needed to be addressed separately. ${ }^{5,6}$ Humans, vehicle and environmental factors play roles before, during and after the accident event. Human error is estimated to account for between 64 and $95 \%$ of all causes of traffic crashes in developing countries. ${ }^{7}$

Reported from developed nations indicated that the use of seat belts is one of the most effective ways to reduce road accident fatalities. ${ }^{8,9}$ Other studies have shown that when a road accident occurs, the use of the seat belt prevents certain types of injuries to vehicle occupants or mitigates their severity. ${ }^{10-12}$ Safety seat belts are preventive measures from mortality because they restrain the body in the original position to a seat which has proved to reduce the risk of fatal injury to front-seat passengers by $45 \%$ and the risk of moderate to critical injury by $50 \%$. The seat belt also helps the driver to control the vehicle in a crash situation as it holds the passenger in place. Serious injuries occurring to passengers in motor vehicles are often caused by people being thrown into each other during a crash. ${ }^{13}$ If a person does not wear the seat belt, that particular person could be thrown from his or her vehicle; through the windshield or door into trees, telephone poles or rocks, or run over by their own or someone else's car. Another reason 
for road traffic accident is using handheld mobile telephone while driving. There is increasing evidence that the use of a handheld mobile telephone while driving a motor vehicle increases the risk of a traffic accident. ${ }^{14-16}$

Developing countries account for over $85 \%$ of the deaths, and close to $90 \%$ of the disability caused by road traffic crashes worldwide. ${ }^{17}$ Also rapidly increasing motorization is outpacing the development of transportation infrastructure. This fact is the primary reason for the increasing numbers and rates of motor vehicle injuries in developing countries (Jacob et al. 2000). Other factors that contribute to the high rate of accident in less developed countries include a high prevalence of old vehicles that often carry many more people than they are often designed to carry, lack of safety belt, poor road design and maintenance and the traffic mix on roads. ${ }^{18}$

In Malaysia, cars are the most common vehicles involved in accidents, followed by motorcycles, Lorries and vans. ${ }^{19}$ According to the Ministry of Health, injuries including road traffic accidents are the third cause of admission and the fifth cause of death in Malaysian. ${ }^{20}$ According to Malaysian Road Safety Council statistics, there are more than ten causes of road accident in Malaysia. The common three causes are speeding (32.8\%), careless driving (28.2\%) and careless overtaking $(15.1 \%)$. It showed that the driver's behavior is the main cause of road accidents, contributing to $76.1 \%$ of all the causes of road accidents. Other factors are tailgating (driving too closely behind another vehicle) (3.8\%) and road condition (3\%). ${ }^{21}$ The mandatory seat belt law was enforced in the early seventies following the passing of the seat belt law. No previous studies are available regarding the knowledge attitude and practice towards the road traffic regulation in Malaysia. Therefore, the objectives of this study were to determine the knowledge, attitudes and practice and the factors influencing road traffic accident of university students in Malaysia.

\section{MATERIALS AND METHODS}

This study was conducted over five months from February to June of the academic year 2009 among the students of Management and Science University, Shah Alam, Malaysia. The data was collected through the use of the questionnaire, which consisted of four parts, namely, socio-demographic, knowledge, attitude and practice. The questionnaire contained 27 questions. It was adopted from previous study conducted in Saudi Arabia. ${ }^{23}$ It was distributed randomly to the students of the Faculty of Health and Life Sciences through the lecturers in different departments namely; Medical Science, Biomedicine and Nursing. This was completed under the direct supervision of each lecturer of the departments who returned them to the investigator.

The questions were scored and categorized as follow: for practice, always=4, usually=3, sometimes=2, never $=1$. The practice factor was added and the range of the scores was between 6-24 points. Highest points indicated highest practice. The cut-off point of attitude was 12 . For the attitude, the following scoring system was followed: Convinced about the importance of seat belt; 1 =very weak, 2=weak, 3=strong, 4=very strong. Insistence on passengers' use of seat belt; 1=never, 2=sometimes, 3=usually, 4=always. Reasons that make you use seat belt, $4=$ I like to comply with regulation, $3=1$ am convinced of importance of the use of seat belt, 2 =seat belt has become compulsory practice, $1=$ it is civilization phenomenon. Difficulties you face when you use seat belt, $1=$ restriction of movement, 2= anxiety, 3= forgetfulness/others, 4=no difficulties. Effect of using seat belt, $1=$ no effect on the rate of disabilities, 2 =reduce rate and complications of road traffic accident, $3=$ reduce disabilities caused by road traffic accident, $4=$ reduce the incidence of road traffic accidents. Reason for using seat belt, 4=drivers are convinced of the importance of using seat belt, 3 =positive impact of health education conducted by traffic road departments, $2=$ drivers are afraid of punishment, 1 = others.

The entire attitude factors added and ranged from 6-24 points. The cut-off point of both attitude and practice was 12 . For the purpose of this study, high knowledge, positive attitude and good practice were considered desirable attributes of the participants with higher compliance to road traffic regulations. Data were analyzed using the Statistical Package for Social Sciences Software (SPSS) version 13. T-test and ANOVA were performed to analyze the univariate analysis. Multiple linear regression analysis was used to assess the predictors' variables of exposure to road traffic accident.

\section{RESULTS}

The total number of the participants in this study was 109 students from the Faculty of Health and Life Sciences (FHLS), Management and Science University (MSU), Shah Alam, Malaysia. The mean age of the participant was $20.94 \pm 1.89$ year, minimum age was 18 year and maximum was 26 year. More than half of the participants $89(81.7 \%)$ live in the city. The majority of the students were from the Nursing Department 51 (46.8\%). About 60 (55\%) of the participants had a driving license. However 22 (20.2\%) of them owned cars. For experience of driving, the majority of the participants 49 (45\%) had no experience, followed 25 (22.9\%) had less than or equal to two years of driving experience, then more than two years 35 (32.1\%). More than half of the students 70 (64.2\%) had not been involved in road traffic accident. However 39 (35.7\%) had been involved in one or more than one road traffic accident (Table I).

The majority of the participants 85 (78\%) mentioned that they had moderate knowledge about road traffic regulations and most of them 79 (72.5\%) mentioned that high speed, drivers' lack of awareness about traffic regulation and laws, and drivers' non-compliance 
with traffic rules and regulation were the most important cause of road traffic accidents (Table II).

When the participants asked about the importance of the use of seat belt, about $93.6 \%$ were very strongly/ strongly convinced of its importance. However, on the reasons for using seat belts, $52.3 \%$ felt convinced of its use, followed by seat belt has become compulsory practice $(20.2 \%)$, participants liked to comply with regulations $(17.4 \%)$, then seat belt is civilized phenomenon (10.1\%) (Table III).

The minimum speed reported by the respondents inside the city was $40 \mathrm{Km} / \mathrm{H}$ and maximum speed was $100 \mathrm{Km} / \mathrm{H}$. The minimum speed in the highway was 70 $\mathrm{Km} / \mathrm{H}$ and maximum speed was $180 \mathrm{Km} / \mathrm{h}$. As far as action taken when the respondent remember to fasten seat belt, $36.7 \%$ reported that they try to slow down and then fasten the seatbelt, followed by stop the car and then fasten the seatbelt (31.2\%), the lowest response was reported by the respondent is fasten the seatbelt when any opportunity occurs (7.3\%) (Table IV).

Table I. Socio-demographic of the participants (n =109)

\begin{tabular}{|c|c|c|}
\hline Variable & Number & Percentage $\%$ \\
\hline \multicolumn{3}{|l|}{ Age } \\
\hline$\leq \mathbf{2 0}$ & 41 & 37.6 \\
\hline$>\mathbf{2 0}$ & 68 & 62.4 \\
\hline \multicolumn{3}{|l|}{ Place of resident } \\
\hline City & 89 & 81.7 \\
\hline village & 20 & 18.3 \\
\hline \multicolumn{3}{|l|}{ Department } \\
\hline BMS & 41 & 37.6 \\
\hline BBM & 17 & 15.5 \\
\hline Nursing & 51 & 46.8 \\
\hline \multicolumn{3}{|l|}{ Having driving license } \\
\hline Yes & 60 & 55 \\
\hline No & 49 & 45 \\
\hline \multicolumn{3}{|l|}{ Omn car } \\
\hline Yes & 22 & 20.2 \\
\hline No & 87 & 79.8 \\
\hline \multicolumn{3}{|l|}{ Experience of driving } \\
\hline No experience & 49 & 45 \\
\hline$\leq 2$ & 25 & 22.9 \\
\hline$>2$ & 35 & 32.1 \\
\hline \multicolumn{3}{|l|}{ Exposure to accident } \\
\hline No accident & 70 & 64.2 \\
\hline One accident & 25 & 22.9 \\
\hline Two accident & 6 & 5.5 \\
\hline More than three accident & $\mathbf{8}$ & 7.3 \\
\hline
\end{tabular}

Table II. Knowledge of the participants towards road traffic regulations $(n=109)$

\begin{tabular}{|l|c|c|}
\hline Variable & Number & Percentage \% \\
\hline $\begin{array}{l}\text { knowledge } \\
\text { High }\end{array}$ & 19 & 17.4 \\
Moderate & 85 & 78 \\
Low & 5 & 4.6 \\
\hline $\begin{array}{l}\text { Reason for road traffic accident } \\
\text { High speed alone }\end{array}$ & 13 & 11.9 \\
\hline $\begin{array}{l}\text { Drivers' lack of awareness of traffic } \\
\text { regulations and laws alone }\end{array}$ & 10 & 9.2 \\
\hline $\begin{array}{l}\text { Drivers' non-compliance with traffic } \\
\text { rules and regulations alone }\end{array}$ & 7 & 6.4 \\
\hline All the above reasons & 79 & 72.5 \\
\hline
\end{tabular}

Table III. Attitude of the participants towards road traffic regulations and accidents $(n=109)$

\begin{tabular}{|c|c|c|}
\hline Variables & Nomber & Percentage \\
\hline $\begin{array}{l}\text { Convinced about the importance of seat } \\
\text { belts: } \\
\text { Very strong } \\
\text { Strong } \\
\text { Weak/veryweak }\end{array}$ & $\begin{array}{c}67 \\
35 \\
7 \\
\end{array}$ & $\begin{array}{r}61.5 \\
32.1 \\
6.4\end{array}$ \\
\hline $\begin{array}{l}\text { Insistence on passengers" use of seat } \\
\text { belts: } \\
\text { Always } \\
\text { Sometimes } \\
\text { Usually } \\
\text { Never }\end{array}$ & $\begin{array}{l}35 \\
38 \\
32 \\
4\end{array}$ & $\begin{array}{c}32.1 \\
34.9 \\
29.4 \\
3.7\end{array}$ \\
\hline $\begin{array}{l}\text { Reasons that make you use seat belt: } \\
\text { I like to comply with regulations } \\
\text { I am comvinced of importance of the use } \\
\text { of seat belt } \\
\text { Seat belt has become compulsory practice } \\
\text { It is civilized phenomenon }\end{array}$ & $\begin{array}{l}19 \\
57 \\
22 \\
11\end{array}$ & $\begin{array}{l}17.4 \\
52.3 \\
20.2 \\
10.1\end{array}$ \\
\hline $\begin{array}{l}\text { Difficulties you face when you use seat } \\
\text { belt: } \\
\text { Restriction of movement } \\
\text { Anxiety } \\
\text { Forgetfulness } \\
\text { Nodifficulties } \\
\text { Others }\end{array}$ & $\begin{array}{c}66 \\
4 \\
5 \\
30 \\
4\end{array}$ & $\begin{array}{r}60.6 \\
3.7 \\
4.6 \\
27.5 \\
3.7\end{array}$ \\
\hline $\begin{array}{l}\text { Effects of using the seat belt: } \\
\text { Reduce the incidence of RTA } \\
\text { Reduce disabilities caused by RTA } \\
\text { Reduce mortality rate and complications } \\
\text { of RTA } \\
\text { Not effect on the rate of disabilities }\end{array}$ & $\begin{array}{l}36 \\
37 \\
31 \\
5\end{array}$ & $\begin{array}{c}33 \\
33.9 \\
28.4 \\
4.6\end{array}$ \\
\hline $\begin{array}{l}\text { Reason for using seat belt: } \\
\text { Drivers are afraid of pumishment } \\
\text { Drivers are convinced of the importance } \\
\text { of using seat belt } \\
\text { Positive impact of health education } \\
\text { conducted by traffic road } \\
\text { departments }\end{array}$ & $\begin{array}{r}43 \\
43 \\
20\end{array}$ & $\begin{array}{l}39.4 \\
39.4 \\
18.3\end{array}$ \\
\hline Others & 3 & 2.8 \\
\hline
\end{tabular}

Table IV. Practice of the participants towards road traffic regulations and accidents $(n=109)$

\begin{tabular}{|c|c|c|}
\hline Variable & Nhinber & Percentage $\%$ \\
\hline $\begin{array}{l}\text { Speed } \\
\text { Speed inside the city (mean } \pm \text { SD) } \\
\text { Speed in the higlway (mean }+ \text { SD) } \\
\end{array}$ & $\begin{array}{c}67.06 \pm 12.42 \\
102.48 \pm 16.89 \\
\end{array}$ & \\
\hline $\begin{array}{l}\text { Comply with seat belt use when driving } \\
\text { your car inside city } \\
\text { Always } \\
\text { Sometimes } \\
\text { Usually } \\
\text { Never }\end{array}$ & $\begin{array}{c}49 \\
19 \\
37 \\
4 \\
\end{array}$ & $\begin{array}{c}45 \\
17.4 \\
33.9 \\
3.7 \\
\end{array}$ \\
\hline $\begin{array}{l}\text { Comply with seat belt use when driving } \\
\text { on the highway } \\
\text { Always } \\
\text { Sometimes } \\
\text { Usually } \\
\text { Never }\end{array}$ & $\begin{array}{c}61 \\
9 \\
36 \\
3 \\
\end{array}$ & $\begin{array}{l}2.8 \\
8.3 \\
33 \\
2.8 \\
\end{array}$ \\
\hline $\begin{array}{l}\text { Comply with seat belt use when riding } \\
\text { inside city } \\
\text { Always } \\
\text { Sometimes } \\
\text { Usually } \\
\text { Never }\end{array}$ & $\begin{array}{c}38 \\
22 \\
45 \\
4\end{array}$ & $\begin{array}{c}34.9 \\
20.2 \\
41.3 \\
3.7 \\
\end{array}$ \\
\hline $\begin{array}{l}\text { Comply with seat belt use when riding } \\
\text { car in highways } \\
\text { Always } \\
\text { Sometimes } \\
\text { Usually } \\
\text { Never } \\
\end{array}$ & $\begin{array}{c}48 \\
18 \\
38 \\
5 \\
\end{array}$ & $\begin{array}{c}44 \\
16.5 \\
34.9 \\
4.6\end{array}$ \\
\hline $\begin{array}{l}\text { Comply with seat belt use after its } \\
\text { realization } \\
\text { Always } \\
\text { Sometimes } \\
\text { Usually } \\
\text { Never }\end{array}$ & $\begin{array}{l}39 \\
25 \\
41 \\
4\end{array}$ & $\begin{array}{c}35.8 \\
22.9 \\
37.6 \\
3.7\end{array}$ \\
\hline $\begin{array}{l}\text { Action taken when you remember to } \\
\text { fasten seat belt } \\
\text { I Fasten it immediately } \\
\text { I try to slow down and then fasten it } \\
\text { I stop my car and then fasten it } \\
\text { I fasten it when any opporthnity ocalrs }\end{array}$ & $\begin{array}{c}27 \\
40 \\
34 \\
8 \\
\end{array}$ & $\begin{array}{c}24.8 \\
36.7 \\
31.2 \\
7.3 \\
\end{array}$ \\
\hline
\end{tabular}

\section{Univariate analysis}

Age was significantly influenced by the exposure to traffic road accident among university students. Place of resident and speeding inside the city or in the high- 
ways was not significantly influenced by the exposure to traffic road accident among university students using t-test (Table V). Years of experience were significantly associated with the exposure to road traffic accident. Post Hoc test using Bonferroni test did not show any significance within the three groups. Departments showed a significant association with the exposure of the road traffic accident. Post Hoc test using Bonferroni test showed a significance between BMS students and Nursing students $(p=0.001)$ (Table $\mathrm{VI})$.

Table V. Factors influenced the exposure to traffic road accident among university students $(n=109)$

\begin{tabular}{|l|c|c|}
\hline $\begin{array}{l}\text { Variables } \\
\text { Age } \\
\leq 20 \\
>20\end{array}$ & 3.98 & 0.001 \\
\hline $\begin{array}{l}\text { Place of resident } \\
\text { City } \\
\text { Village }\end{array}$ & 0.22 & 0.825 \\
\hline $\begin{array}{l}\text { Having a driving license } \\
\text { Yes } \\
\text { No }\end{array}$ & 1.6 & 0.111 \\
\hline $\begin{array}{l}\text { Speed inside the city } \\
<=70 \\
>70\end{array}$ & 0.61 & 0.543 \\
\hline $\begin{array}{l}\text { Speed in the highway } \\
\text { <100 } \\
>100\end{array}$ & 0.07 & 0.943 \\
\hline
\end{tabular}

Table VI. Factors influenced the exposure to traffic road accident

\begin{tabular}{|l|c|c|}
\hline $\begin{array}{l}\text { Variable } \\
\text { Years of experience } \\
\text { No experience } \\
\text { < 2years } \\
\text { >2 years }\end{array}$ & $\mathbf{f} .62$ & P value \\
\hline $\begin{array}{l}\text { Department } \\
\text { BMs } \\
\text { BBM } \\
\text { Nursing }\end{array}$ & $\mathbf{8} .86$ & $\mathbf{0 . 0 0 1}$ \\
\hline
\end{tabular}

\section{Multivariate analysis}

Multivariate analysis using the multiple linear regression method showed that age was significantly associated with the exposure to the accident; the older students $>20$ have higher 0.5 points exposure to accident compared to the reference group. Attitude was significantly associated with exposure to the accident; with increase of the attitude scores, the exposure of accident will decrease 0.08 points (Table VII).

Table VII. Model building for factors influenced the exposure to traffic road accident

\begin{tabular}{|l|c|c|c|c|}
\hline \multicolumn{1}{|c|}{ Variable } & B & SE & Beta & p value \\
\hline constant & 0.996 & & & \\
\hline $\begin{array}{l}\text { Age } \\
\text { Reference group ( } \\
>20 \text { years }\end{array}$ & 0.575 & 0.165 & 0.312 & 0.001 \\
\hline \multicolumn{1}{|c|}{ Attitude } & -0.85 & 0.327 & 0.233 & 0.001 \\
\hline
\end{tabular}

$\mathrm{F}$ value $=11.75, \mathrm{p}=0.001, \mathrm{R} 2=0.18$

\section{DISCUSSION}

It is generally accepted that vehicle crashes cannot be prevented completely, but that some of the injuries and severity can be prevented or minimized by simple protective ways such as using seat belts for car users. Many factors are the causes of road traffic accidents: car conditions, driver attitude, and the road conditions. The objective of this study was to determine the knowledge, attitudes and practice towards road traffic regulation among university students in Malaysia. Most of the participants had no cars $(79.8 \%)$; this was due to the fact that the students at this age don't have income to start to pay the car installment. Fifty five percent of the participants had driving licenses. This was due to the point that the students were above the legal age for owning a driver's license. Approximately $35.7 \%$ had been involved in one or more than one road traffic accident. Most of the participants $(72.5 \%)$ mentioned that high speed, drivers' lack of awareness about traffic regulation and laws, and drivers' non-compliance with traffic rules and regulation were the most important cause of road traffic accidents. A similar finding was reported by other researchers. ${ }^{22,-25}$

The majority of the participants 85 (78\%) mentioned that they had moderate knowledge about road traffic regulations. A similar finding reported by Al-Khaldi, stated that most of the participants considered themselves knowledgeable about road traffic regulations. ${ }^{22}$ Similar findings were reported by other researchers. ${ }^{25,26}$ As far as importance of the use of seat belt is concerned, about $93.6 \%$ were very strongly/strongly convinced of its importance. The reason for using seat belts was that the participants felt convinced of its use $(52.3 \%)$.

As far as univariate analysis is concerned, years of experience were significantly associated with the exposure to road traffic accident. Similar finding reported by stated that experience of less than two years demonstrated a positive attitude towards obedience to speed rules relative to these experienced over two years. ${ }^{27}$ This may be due to the idea that drivers get more experienced their self-confidence increase and they bend the traffic rules. Speeding inside the city or in the highways was not significantly influenced by the exposure to traffic road accident among university students. This may be due to the point that the mean speed of the study participant is within the safe range $67.06 \mathrm{Km} / \mathrm{h}$ inside the city, and 102.48 on the highway. Departments showed a significant association with the exposure of the road traffic accident. This may be due to the fact that the BMS students are older than Nursing students.

In multivariate analysis, this study found a strong positive relationship between road traffic accidents and age of university students in Malaysia. The older students $>20$ have higher 0.5 points exposure to accident compared to the younger group $\leq 20$. The possible explanation could be because the adolescents 
and young adults were major road users and thus exposure road traffic accidents. This represents a great loss in the productivity among the young adult age group. A similar finding showed that age mediated the relationship between the commission of driving violations and attitudes towards traffic laws. ${ }^{28}$ The commission of traffic violations is more strongly related to the evaluation of traffic laws among older drivers than among younger drivers. Some theories might be more suitable to the description of the attitudesbehavior relationship among younger drivers than to that of older drivers and the reverse. For example, the theory of planned behavior, describing a rational relationship between attitudes and behavior might be more relevant to account for the relationship between the attitudes and driving behavior of older drivers. ${ }^{29}$ On the other hand, a model describing spontaneous behavior and its relations to attitudes, such as the attitude to behavior process model, might be more applicable to younger drivers. ${ }^{30}$ Positive relationship of accidents with younger age of drivers in this study is similar with reports from other countries that young drivers have a higher accident risk and a higher fatality rate than older drivers. ${ }^{31,32}$

Also this study found a strong positive relationship between road traffic accidents and attitude of the participants. Other studies reported that attitudes remain the most significant factor in increasing the rate of road traffic accidents. ${ }^{22,25} \mathrm{~A}$ similar finding reported by Malaysian Road Safety Council statistics showed that the driver's behavior is the main cause of road accidents, contributing to $76.1 \%$ of all the causes of road accidents. The limitation of this study is that this study was conducted among Management and Science University students thus the result of this study may not represent the knowledge, attitude and practice among university students nationally.

\section{CONCLUSION}

The study participants had moderate knowledge about road traffic regulations and most of them mentioned that high speed, drivers' lack of awareness about traffic regulation and laws, and drivers' non-compliance with traffic rules and regulation were the most important cause of road traffic accidents. Almost all students were very strongly/strongly convinced of seatbelts importance. Age and attitude were significantly associated with the exposure to the road accident.

\section{Acknowledgment}

Authors would like to thank the Head, Department of Nursing for assisting in data collection among nursing students.

\section{Author Disclosure Statement}

No competing financial interests exist

\section{REFERENCES}

1. World Health Organization. Report on injuries and violence prevention: Road traffic injuries. 2002; World Health Organization, Geneva.

2. Peden MM, Krug E, Mohan D, et al. A five year WHO strategy for road traffic injury prevention. 2001; World Health Organization, Geneva.

3. Binder S, Runge JW. Road Safety and Public Health: A US perspective and the global change. Traff Injury Prev 2002; 7:3-9

4. Murray C, Lopez A. The global burden of disease. Harvard University Press, Cambridge, 1996.

5. Robertson LS. Injury epidemiology. Oxford University Press, London, 1992.

6. Johnston I. Action to reduce road causalities. World Health Forum 1992; 13:154-62

7. Transport Research Laboratory. TRL Report 445, 1990.

8. Green RN. Fatal injuries to restrained passenger car occupants in Canada: crash modes and kinematics of injury. Accid Anal Prev 1994; 26;207-14

9. Evans L. Safety-belt effectiveness: The influence of crash severity and selective recruitment. Accid Anal Prev 1996; 28:423-33

10. Arajaevi, E. Retrospective analysis of chest injuries in 280 seat belt wearers. Accid Anal Prev 1988; 20:251-9

11. Campbell BJ. Change in injuries associated with safety belt laws. Accid Anal Prev 1991; 23:87-93

12. Shibata A, Fukuda K. Risk factors of fatality in motor vehicle traffic accidents. Accid Anal Prev 1994; 26:391- 7

13. Buseck V, Geller ES. The Vehicle Safety Reminder: Can Refinements Increase Safety Belt Use? Technical Report for General Motors Research Laboratories, 1984.

14. Lamble D, Kauranen T, Laakso M, Summala $H$. Cognitive load and detection thresholds in car following situations: safety implications for using mobile (cellular) telephones while driving. Accid Anal Prev 1999; 31:61723

15. Violanti JM. Cellular phones and traffic acci dents. Public Health 1997; 111:423-8

16. Violanti JM. Cellular phones and fatal traffic collisions. Accid Anal Prev 1998; 30:519-24

17. Krug E. Injury: a leading cause of the global burden of disease. 1999; World Health Orgaization, Geneva.

18. Odero W, Garner P, Zwi A. Road traffic injuries in developing countries: a comprehensive review of epidemiological studies. Trop Med Int Health 1997; 2:445-60

19. Royal Malaysian Police. Statistical report road accident Malaysia. Bukit Aman, Kuala Lumpur: Traffic Police Headquarters, 2002.

20. Ministry of Health Malaysia. Department of 
Public Health. Annual Report, 2004.

21. Suret S. Road safety issues in Malaysia. Symposium on Road Safety. Road Safety Department. Ministry of Transport Malaysia, annual report, 2001.

22. Al-Khaldi YM. Attitude and practice towards road traffic regulations among students of health Sciences College in Aseer region. J Fam Community Med 2006; 13:109-13

23. Ansari S, Akhdar F, Mandoorah M, Moutaery $\mathrm{K}$. Causes and effects of road traffic accidents in Saudi Arabia. Public Health 2000; 114:37-9

24. Badawi IA, Alakija W, Aziz MA. Road Traffic accidents In Asir Region, Saudi Arabia: Pattern and Prevention. Saudi Med J 1995; 16: 257-60

25. Nofal FH, Saeed AA, Anokute CC. Aetiological factors contributing to road traffic accidents in Riyadh city, Saudi Arabia. J R Soc Health 1996; 116:304-11

26. Al-Ghamdi KS. Behavior and practice of drivers towards road traffic safety at Naval Base in Jubail. J Fam Community Med 1995; 2:41 $-8$

27. Yilmaz V, Eray HÇ. Risky driving attitudes and self-reported traffic violations among Turkish drivers: the Case of eskișehir. Doğuș Üniversitesi Dergisi 2006; 7 127-38

28. Yagil D. Gender and age-related differences in attitudes toward traffic laws and traffic violations. Transp Res 1998; 1:123-35

29. Ajzen I, Fishbein M. Understanding Attitudes and Predicting Social Behavior. PrenticeHall, New Jersey, 1980.

30. Fazio RH. On the power and functionality of attitudes: the role of attitudes accessibility. In A R Pratkanis, S J Breckler \& A G. Greenwald (Eds.), Attitudes structure and function (pp. 153-179). Erlbaum, New Jersey, 1989.

31. Peden $M$, Scurfield R, Sleet $D$ et al. World report on road traffic injury prevention. 2004; World Health Organization, Geneva.

32. Zador PL, Krawchuk SA, Voas RB. Alcoholrelated relative risk of driver fatalities and driver involvement in fatal crashes in relation to driver age and gender: an update using 1996 data. J Stud Alcohol 2000; 61:38795 